\title{
20年間の官界写真測量のあゆみ
}

国土地理院 平井雄

1.はじめに

多少なりとも，計測の媒体として写真を使ったり，写真判読を行ったりしている国や地方自治体 等の機関は, かなりの数にのぼるであろう。それらの機関における動きを全て総括することはほと んど不可能に近い。

そこで, 当学会と関係の深い国の機関 : 国土地理院, 林業試䮖所, 地質調查所, 水路部等をとり あげ, 当学会の学会誌での発表を中心に, これらの機関のはたした役割, 実施した研究等を簡単に ふり返って，この 20 年間の官界における写真測量のあゆみとする。

\section{2. 主著論文の数}

機関紙のVol.1 から Vol．19 までに載った主著論文は，216 あるが，そのうち国の機関の職員 によって書かれたものは 38 ，ほぼ 5 分の 1 である。思ったより少ないという気がしないでもない が，案外こんな処が官界と呼ばれる分野からの写真測量の発展に対する寄与の正直な姿なのかもし れない。

以下，各機関毎にどんな課題が主著論文及び資料において取りあげられたかそみてみよう。

\section{3. 各機関毎の論文}

(a) 国土地理院

国土地理院は測量を主たる業務とする機関だけあって，学会誌に載った主著論文の数も 29 と一 番多い。論文は当然のことながら，狭義の写真測量と写真判読に分類できる。

写真測量に属するものには,

・解析空中三角測量に関寸る村岡の一連の論文, 即ち

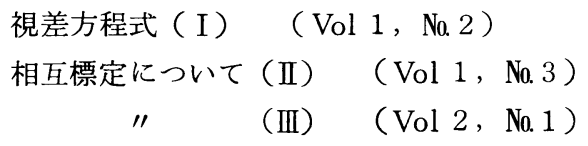

接続標定における誤差について（I）（Vol 2， No. 4）

" (II) (Vol 3, No.1)

絶対標定における誤差について（I）（Vol 4, №.1）

" (II) ( Vol 4, No.2)

・測量成果の検査結果及び精度に関するもの

コンター図化の精度（尾崎 Vol 2, No.1）

三級図化機を用いて描画した中縮尺図の等高線の精度と地形表現について（西村他 Vol 2,

№. 1 )

中縮尺図の等高線の精度（西村 Vol 3, No. 3)

標定の精度について（尾崎 Vol 5，№.1）

国土基本図の精度について（尾崎他 Vol 5， No.2）

対空標識検査結果の分析 (大吉 Vol 6, No.3)

等高線の精度（尾崎 Vol 12, N0.4） 
・機械に関するもの

測機舎製アッフィン図化機M 3 について（松田・垣下 Vol 5， N N $0.2 ）$

新しい図化機についての一つの試案（垣下 $\operatorname{Vol} 7$, N0.4）

中縮尺図化機ニコンプロッターについて（平井 Vol 8, No.4）

・空中三角測量に関するもの

ブロック調整の限界（尾崎 Vol 10， No. 3 ）

解析空中三角測量の閉合差の統計的検討 (秋山他 Vol 14, No.1)

空中三角測量における配点状況の影響評価の一手法（秋山 Vol 16， N N . 4 )

• その他

「ピクトマップ」線画写真図について（杉本 Vol 8, No.4）

デジタルカラー装置の検査 (石原 Vol 11， N N o.4)

カメラの近似的検定の一方法（尾崎 Vol 13，№.4）

写真判読に属するものは

・雪の調査に関するもの

空中写真による積雪調査の実験的作業とその成果（五百沢 Vol 2, №.3）

なだれ危険度による山地斜面の分類について（大竹 Vol 9， No.1）

雪面上の割れ目の $1 \cdot 2$ の性質（保谷 Vol 13，№.1）

・災害調査に関するもの

新潟地震と photo Survey（馬籠 Vol 3, No. 3 )

写真判読による長崎県北松浦半島の地すべり地形解析（I）（上西 Vol 6, No.4）

- その他

空中写真でみるカナダの地理 $<1>$ (大竹 Vol 5, No.3）

$$
\text { " }<2>\text { (大竹 } \mathrm{Vol} 6, \text { №.1) }
$$

である。

村岡の論文を別とすれば，ほとんどが，地理院の業務に直接関係したテーマである。

これは，基本測量の実施を担当するとともに，公共測量に対して技術的助言を行なう地理院の性 格の反映とみることができる。

その意味では，わが国における測量の技術的な基準を定めた作業規定の作成において国土地理院 のはたした役割は重要なものがある。

国土基本図作業規程は，中央自動車道作業等の経験に基づいて，昭和 36 年に作成された。

写真測量による大縮尺図作成の作業規程としては, わが国における最初のもので, その後, 各方 面で作成された大縮尺写真測量の作業規程はほとんどこの規程に準じて作られている。

これにより，わが国の写真測量による大縮尺図作成の工程は民間会社におけるそれを含めて統一 されることになり，わが国の大縮尺図の質の向上に大きく貢献した。

規程の整備はその後も寸すめられ，39 年には骨格図の作業規程が，40 年には写真図の作業規程 がそれぞれ作られ今日に及んでいる。

写真測量による図化は大縮尺図だけでなく，中縮尺地形図作成に扔いても行なわれているが，39 年にはムルチプレックスによる図化作業の規程が，40 年には精密図化機による図化の規程がそれ ぞれ作られる。

これらの規程は，47年統合され基本図測量作業規定となり，その後多少の加除訂正を加えられ 今日の規定におよんでいる。

作業規程だけでなく，国土地理院は，技術基準の設定についての作業も実施している。

技術基準には, 監督や検査の基準といったソフト的なものと, 航空カメラや図化機の性能基準と 
いったハードなものがある。

監督や検査の技術基準は，本来地理院が発注する作業に関寸るものであったが，建設省を通じ， 他の機関の基準としても採用されるようになった。これによって，運用の適否を別とすれば，外注 方式による測量作業の実施に必要な規定及び要領は全て整ったことになる。

ソフトな規程等の整備に比較するとハードに対する基準の設定ははるかに遅れている。写真測量 機器のうちで検定を要する主なものは, カメラ, コンパレーター, 図化機, 描画台, オルソプロジ ェクター等であるが，そのいづれに対しても，成文化された検定要領内至は技術基準は作られてい ない。

勿論, 地理院では, これらに対する検定要領の必要性は十分誌識しており, その整備をすすめて いる。

現在, 航空カメラについての性能基準及び検定要領がほぼ完成しており, 近い将来実作業に適用 されることと思われる。

地理院は，測量を主たる業務とする国の機関として，上に述べたように，既開発の技術を実際の 写真測量作業に適用するために必要な各種規程及び技術基準の整備を図るとともに，新しい技術の 研究, 開発にも努めている。

地理院は, 54 年筑波の研究学園都市に移転したが, その際整備された機器をみることによって 地理院が，当面，どのような研究が必要だと考えているかを知ることができる。

写真測量関係で, 筑波で新たに整備された機器は,
(1)カメラ検定関係
(3)在来型のアナログ図化関倸
(1) 歪曲収差測定装置
アビオマップ AMH
(ii) MT F 測定装置
(4)地上写真測量関係
(iii) シャッター速度測定装置
(i) 写真経緯儀
(VV) フィルム面平坦度測定装置
(ii) 地上写真測量用カメラ（UMK-10）
（V）像面照度測定装置
(iii) 地上写真図化機（テクノカルト）

(2)地図の数值処理関係

（i） 解析図化機（プラニコンプ C $-100 ）$

(5)リモート・センシング関倸

(ii) 実体図化機（アビオマップAMU）

(i) 画像処理システム (PIXEL)

(iii) 対話型図形処理システム（カルマー）

(ii) マルチバンドカメラ

(iii) マルチスペクトルビューア

(V) 野外赤外放射計

以上である。

現在，(1)，(2)及び(5)のテーマに重点をおいた研究がすすめられている。

(b) 林業試験所

学会誌に載った主著論文は,

日本における森林航測研究の概要 (中島 Vol 1, №.2)

赤外線カラー写真の色分解に上る市外地域植物像の分離抽出 (中島 Vol 8, №.1)

写真情報による森林の数量解析（中島 Vol 9, No.21）

資源衛星データによる首都圈の自然環境度の観測（中島 Vol 12，№.21）

の 4 件であるが，林業関係は，古くから空中写真を使った調査が盛んに行われた分野であり，写真 測量関倸の秀れた業績も沢山ある。それに関しては，例えば，中島の「空中写真利用による森林調 査法に関する研究」（林業試験場研究報告第 251 号別刷）に詳しい。

学会の講演では, この他判読写真材積表による小班材積の推定について (金谷 37), Data color による赤外写真の測光試験結果 (中島 46 年), 資源衛星データを用いた北関東緑地保全計画（中 島・天野 51 年) 等がある。 
林業における写真測量関係の事業では，オルソフォトマップの利用が顕著である。

オルソフォトマップは, 業界が中心となり, 一時非常に積極的に導入を図ったが, 実際には林業 以外の分野では当初期待された程には定着しなかった。

林業の分野では, 写真から地形図上への移写が不要になる等の利点があるため, 大巾にとり入れ られ，オルソフォトの最大のユーザーとなっている。

リモートセンシング関係の研究では, 樹木の状態とクロロフィルによる赤外吸収の関係を中心と して秀れた研究が行なわれ，又ミニコン向けのソフトの開発もすすんでいる。

(c) 地 質調查所

学会誌に載った主著論文は,

航空写真による地質災害調査の可能性と限界（松野 Vol 4, No. 3 )

草津一万座地熱異常地域の熱赤外映像撮影結果（長谷・西村 Vol 12，№.3）

の 2 件であるが，講演会での発表は比較的多い，主なものをあげると，

航空写真による地过り地形の判読について（岡 37 年）

岡山県阿哲石灰石鉱床の航空写真に上る地質（河田・西村 37 年）

宮城県思首地区地質調査報告（松野 39 年）

地熱異常地の赤外線映像について（松野他 41 年）

赤外線映像による地温探査についての研究 (長谷 45 年)

フィルムサンドイッチ法を併用した地質構造判読例（長谷・西村 47 年）

等がある。植生に覆われた地域の多いわが国では, 地形を媒介としない photo-geology の育つ場は それ程大きくなく, 研究者の関心は, エネルギー問題, 環境問題が重要な課題として取りあげられ るようになるのと比例して赤外映像の撮影及び処理の問題に移っていったのかもしれない。

(d) 水 路 部

学会誌に載った主著論文は,

海上交通流調査における空中写真の利用について（杉浦 Vol 3， No.1）

渡海空中三角測量について（杉浦他 Vol 7, N0.4）

の 2 件である。

講演会での発表には，

水路測量における空中写真の利用（I）（杉浦・岩崎 38 年）

周防灘沿岸における砂浪の写真判読（茂木 38 年）

がある。

4.おわりに

以上，空中写真を業務の中で使うことの多い国の機関 4 つをとりあげ，そこでの，写真測量に関 係のある研究及び業務の動きを学会誌の主著論文の課題をとおしてとらえ, それによって，与えら れた課題「官界写真測量のあゆみ」を知ろうといら試みを行なったが，旨くいったとは到底思えな い。その原因は, 能力の不足は勿論として, 「最近 20 年の官界写真測量」といら課題設定にもある ように思える。 20 年前といえば，民間で云えば，今日の大手と呼ばれる会社が一応の体制を整え その後の急速な成長のスタートに着いた時であり, 大学では, 東大の丸安研を中心に写真測量を課 題として本格的な研究に取りかからうとしていた時である。それ以降両者がそれ迄地理院等国の機 関がはたしていた役割のかなりの部分をとって代ることになる。例えば，外国からの新しい機器の 導入にしても民間主導型に移ったし，学会誌の主著論文も大学・民間の人達によるものが大部分と なった。今後は, 官界というような単位ではなく, 学会を中心として研究されるのが望ましい。 